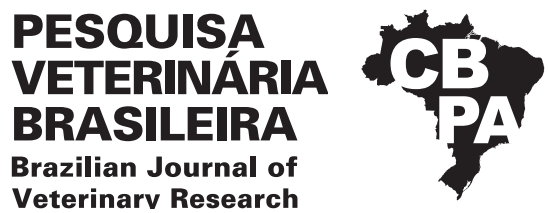

\title{
Influence of seasonality on the physiological and seminal parameters of buffaloes in the western region of Pará ${ }^{1}$
}

\author{
Sâmia R.S. Castro ${ }^{2 *}$ (D) , Leticia S. Rebelo ${ }^{3}$, Onildo S. Fernandes Junior ${ }^{3}$, \\ Alessandra S. Belo-Reis ${ }^{4}$, Kedson A.L. Neves ${ }^{2}$, Welligton C. Silva ${ }^{5}$, \\ Adriana C. Morini ${ }^{2}$ and William G. Vale ${ }^{2}$
}

\begin{abstract}
Castro S.R.S., Rebelo L.S., Fernandes Junior O.S., Belo-Reis A.S., Neves K.A.L., Silva W.C. \& Vale W.G. 2020. Influence of seasonality on the physiological and seminal parameters of buffaloes in the western region of Pará. Pesquisa Veterinária Brasileira 40(12):1048-1053. Departamento de Medicina Veterinária, Universidade da Amazônia, Rua Rosa Vermelha 335, Aeroporto Velho, Santarém, PA 68010-200, Brazil. E-mail: samiarubielle@hotmail.com

Awareness of the physiological changes that occur when animals are subjected to climatic changes that are considered stressful is essential to maintain animal welfare and to be able to exploit their reproductive potential efficiently and rationally. The present study was carried out to evaluate climatic variables' influence on physiological parameters, and Murrah buffalo ejaculates reared in a humid tropical climate in the Amazon. The immediate analyzes pertinent to the physical and morphological characteristics of the ejaculates were carried out and corresponded in the rainy season (RS) volume of $3.4 \pm 2.0 \mathrm{~mL}$; the mass activity of $4.4 \pm 0.5$; motility of $80.4 \pm 5.6 \%$; vigor of $4.4 \pm 0.4$; concentration of $657,300 \pm 237,865.1 \times 106 \mathrm{sptz} / \mathrm{mL}$; major defects of $9.0 \pm 2.6 \%$; minor defects of $11.2 \pm 3.9 \%$; total defects $20.2 \pm 5.3 \%$ and sperm plasma membrane integrity (SPMI) $84.8 \pm 5.6 \%$, whereas in the non-rainy season (nRS), the results were $4.0 \pm 2.1 \mathrm{~mL}$; the mass activity of $3.0 \pm 1.0$; motility of $56.2 \pm 13.4 \%$; vigor of $3.0 \pm 1.0$; concentration of $586,000 \pm 291,925.9 \times 106 \mathrm{sptz} / \mathrm{mL}$; major defects of $20.8 \pm 9.9 \%$; minor defects of $27.5 \pm 6.3 \%$; total defects $48.3 \pm 9.3 \%$ and SPMI of $57.9 \pm 12.4 \%$. Furthermore, a statistical difference $(P<0.05)$ was observed for the parameters mass activity, motility, vigor, major defects, minor defects, total defects, and sperm plasma membrane integrity between both periods. The data on heart frequency, superficial temperature (head, back, groin, and scrotal pouch) showed a statistical difference between both periods $(P<0.05)$. To conclude is necessary specific management in the non-rainy season that thermal stress is not a determining factor in reducing the reproductive quality of buffaloes; it is necessary to use means to improve animal welfare; one alternative is to use baths regularly for these animals or provide constant access to areas of rivers or lakes, as well as shading, preventing the buffaloes from being directly exposed to the unfavorable thermal environment.
\end{abstract}

INDEX TERMS: Seasonality, physiology, semen, buffaloes, Pará, Amazon, Bubalus bubalis, environment, reproductive parameters.

\footnotetext{
${ }^{1}$ Received on August 15, 2020.

Accepted for publication on September 10, 2020.

${ }^{2}$ Laboratório de Biotecnologia Animal, Universidade Federal do Oeste do Pará (UFOPA), Rua Vera Paz s/n, Tapajós, Bairro Salé, Santarém, PA 68040255. Brazil. *Corresponding author: samiarubielle@hotmail.com

${ }^{3}$ Centro Acadêmico de Medicina Veterinária, Universidade da Amazônia (UNAMA), Rua Rosa Vermelha 335, Aeroporto Velho, Santarém, PA 68010200, Brazil. E-mail: leticiarebelo@hotmail.com, jr.asd@hotmail.com

${ }^{4}$ Professor, Curso de Medicina Veterinária, Universidade da Amazônia (UNAMA), Rua Rosa Vermelha 335, Aeroporto Velho, Santarém, PA 68010200, Brazil. E-mail: alessandra.belo.reis@gmail.com

${ }^{5}$ Master's student in Animal Health and Production, Universidade Federal Rural da Amazônia (UFRA), Av. Presidente Tancredo Neves 2501, Terra Firme, Belém, PA 66077-830, Brazil. E-mail: welligton.medvet@gmail.com
}

RESUMO.- [Influência da sazonalidade nos parâmetros fisiológicos e seminais de búfalos da região oeste do Pará.] O conhecimento das alterações fisiológicas que ocorrem quando os animais são submetidos a alterações climatológicas consideradas estressantes é fundamental para manter o bem-estar animal, e poder explorar o seu potencial reprodutivo de forma eficiente e racional. 0 presente estudo foi realizado com o objetivo de avaliar a influência de variáveis climáticas sobre parâmetros fisiológicos e de ejaculados de búfalos, da raça Murrah, criados em clima tropical úmido da Amazônia. As análises imediatas pertinentes às características físicas e morfológicas dos ejaculados 
foram realizadas e corresponderam no período chuvoso (PCh) o volume de $3,4 \pm 2,0 \mathrm{~mL}$, turbilhonamento de $4,4 \pm 0,5$; motilidade de 80,4 $\pm 5,6 \%$; vigor de 4,4 40,4 ; concentração de $657.300 \pm 237.865,1 \times 10^{6} \mathrm{sptz} / \mathrm{mL}$; defeitos maiores de $9,0 \pm 2,6 \%$; defeitos menores de $11,2 \pm 3,9 \%$; defeitos totais de $20,2 \pm 5,3 \%$ e integridade da membrana plasmática (IMP) de $84,8 \pm 5,6 \%$, enquanto que no período não chuvoso ( $\mathrm{PnCh}$ ), os resultados foram de $4,0 \pm 2,1 \mathrm{~mL}$; turbilhonamento de $3,0 \pm 1,0$; motilidade de $56,2 \pm 13,4 \%$; vigor de $3,0 \pm 1,0$; concentração de $586.000 \pm 291.925,9 \times 10^{6} \mathrm{sptz} / \mathrm{mL}$; defeitos maiores de $20,8 \pm 9,9 \%$; defeitos menores de $27,5 \pm 6,3 \%$; defeitos totais de 48,3 $\pm 9,3 \%$ e IMP de $57,9 \pm 12,4 \%$. Observou-se diferença estatística $(P<0,05)$ para os parâmetros movimento de massa, motilidade, vigor, defeitos maiores, defeitos menores, defeitos totais e integridade da membrana plasmática entre os dois períodos. Dados de frequência cardíaca, temperatura superficial (cabeça, dorso, virilha e bolsa escrotal) diferiram estatisticamente entre os períodos $(P<0,05)$. Conclui-se que se faz necessário usar de um manejo específico no período não chuvoso para que o estresse térmico não seja um fator determinante na redução da qualidade reprodutiva dos búfalos, para isto se faz necessário utilizar de meios para melhorar o bem-estar animal, sendo uma das alternativas fazer uso de banhos regularmente para estes animais, ou disponibilizar acesso constante destes a áreas de rios ou lagos, assim como sombreamentos, evitando que os búfalos fiquem expostos diretamente ao ambiente térmico desfavorável.

TERMOS DE INDEXAC̄̃̃: Sazonalidade, fisiologia, sêmen, búfalos, Pará Amazônia, Bubalus bubalis, meio-ambiente, parâmetros reprodutivos.

\section{INTRODUCTION}

In Brazil, four breeds of buffalo are recognized: Carabao, Jafarabadi, Mediterranean, and Murrah. According to data from the Ministério da Agricultura (2011), the buffalo herd in Brazil is estimated at around 1.17 million head, with the northern region having the highest concentration with 720 thousand heads, with $39 \%$ of the national herd found in the state of Pará, followed by the northeast and southeast regions, with 135 and 104 thousand heads, respectively (Vilela 2013).

Despite being considered rustic animals and easy to adapt to, compared to cattle, buffaloes are more sensitive to direct solar radiation and environments with high temperatures due to their specific morphological characteristics. Among them, such as the high concentration of melanin in the skin and hair that provides low reflectivity, which helps to have a high absorption of heat when exposed directly under the sun, low quantity and efficiency of sweat glands that hinders heat loss through sweating; low hair density and the epidermis layer of thick skin, which reduces heat loss through conduction and irradiation (Joshi et al. 1968, Garcia 2006, Ablas et al. 2007, Barbosa et al. 2007).

In regions of tropics and subtropics, where the climate is hot and humid, buffalo are adapted to live, and this is due to their semi-aquatic nature in which it seeks to keep the body submerged in water to reduce the effect of heat. This occurs mainly when the temperature and humidity index reaches the value of 85 temperature and humidity index (THI), which is common in tropical regions, and when the discomfort of buffaloes is most significant (Ablas et al. 2007). Although the West of Pará has a tropical climate, said to be adaptable by buffaloes, the temperatures reached are higher than the acceptable temperatures. In these regions, the high environmental temperatures are constant (Garcia 2013).

The knowledge of the physiological changes that occur when animals are subjected to climatic changes considered stressful is essential to maintain animal welfare and to be able to exploit their reproductive potential efficiently and rationally. Thus, handling is a determining factor for these animals to reproduce. In addition to the use of biotechnologies, they need an environment closer to their natural environment, with the presence of shading and water, so that their physiological changes resulting from thermal stress do not become determining factors for a decrease in their reproductive quality (Vale 2002, Almeida et al. 2015, Castro et al. 2017).

The buffaloes have gained prominence in meat and milk; with that, the search for biotechnology techniques, such as artificial insemination (AI) and cryopreservation, has become as crucial for buffaloes as they are for cattle. Along with cryopreservation techniques, there was a concern to certify that the semen used in this process was of quality. Furthermore, only morphological aspects of the semen were taken into account, forgetting to analyze the possible influences that external factors such as time and time of harvest that could influence the reproductive performance of these animals (Sally et al. 2015).

Based on this information, this study's objective was to analyze the physiological, behavioral, and seminal changes of buffaloes in the rainy and non-rainy periods in the municipality of Santarém, Pará state, Amazônia.

\section{MATERIALS AND METHODS}

All analyses followed the Ethics Committee on the Use of Animals at the "Universidade Federal do Oeste do Pará", filed under number No. 03003-2017. For the present study's execution, seminal processing and laboratory analyses were carried out at the Animal Biotechnology Laboratory of the "Universidade Federal do Oeste do Pará", Santarém, Pará, Amazonia, Brazil and located at $2^{\circ} 25^{\prime} 39.1^{\prime \prime}$ S 54 $44^{\circ} 1^{\prime} 48.6^{\prime \prime} \mathrm{W}$ and altitude of 15 meters. The local climate is of the Af type, characterized by being a rainy tropical climate, being classified as Am3 according to the Köppen system (Köppen \& Geiger 1928). Annual rainfall ranges from 2,000 to $2,500 \mathrm{~mm}$, with total rainfall below $60 \mathrm{~mm}$ during the month with less rain. The maximum air temperature ranges from 30.5 to $32.0^{\circ} \mathrm{C}$, and the minimum varies between 21.0 and $22.5^{\circ} \mathrm{C}$ (Köppen \& Geiger 1928). The rainy period is from March to June and not rainy from July to November in the study region. In Pará, Vale (1988) observed that the difference in light is small throughout the year. The buffalo behaves as continuous polystyrene; that is, the behavior of seasonal reproductive activity is less pronounced.

As semen donors, five buffalo bulls were selected from a batch of 12 , pre-evaluated by andrological examination (the criterion used was concerning the sperm quality presented). The donors were between 2 and 4 years old and had an average weight of $709.5 \pm 35.5 \mathrm{~kg}$. They were kept in a semi-confinement regime, with access to the Canarana forage (Echinochloa polystachia), corn, soy and sorghum ration, water and mineral salt ad libitum, and stalls with natural shade for resting. Before this study, the animals were dewormed and vaccinated.

Semen was obtained routinely from all bulls using the artificial vagina harvesting method. According to Sansone et al. (2000), Vale (2011), buffaloes can be considered easily adaptable animals and be able to collect semen using this method. Ten semen collections 
were performed per animal each period, thus totaling 50 samples for the rainy period and 50 for the non-rainy period. A minimum period of two days of rest was maintained for each new harvest of the animal. Immediately after collection, the ejaculate was evaluated by an experienced operator for appearance (milky), color (white, yellowish-white, white-brown), volume (mL, graduated collection tube), sperm motility, mass movement or whirlwind, vigor, following the norms established by the CBRA (2013). The concentration was assessed through the Neubauer chamber with a 1: 200 dilution in formalin saline as described by Vale (2011), sperm morphology by wet drop technique with phase-contrast microscopy evaluation, the integrity of the sperm plasma membrane was assessed by the hyposmotic test (HOST), as Rasul et al. (2000) and Barros et al. (2007).

In animals, physiological parameters such as heart rate (HR), respiratory rate (RR), rectal temperature (RT), superficial temperature (ST - subdivided into areas of the head, back, groin and testicles) were measured. For HR measurements (bpm), a stethoscope was used; the respiratory rate was determined by observing the chestabdominal area and counting the breathing movements for one minute $(\mathrm{mpm})$; to determine the rectal temperature $\left({ }^{\circ} \mathrm{C}\right)$, a digital thermometer was used, and the body surface temperature $\left({ }^{\circ} \mathrm{C}\right)$ was measured with an infrared digital thermometer with a laser sight $\left(-50^{\circ} \mathrm{C}\right.$ to $380^{\circ} \mathrm{C}$, Benetech ${ }^{\circledR}$, model: GM300) in the head, back (hip), groin and testicles.

A mini weather station (WS-GP1 Weather Station, AT DeltaDevices Ltda $^{\circledR}$ ) was installed at the experiment site to measure room temperature $\left({ }^{\circ} \mathrm{C}\right)$, percentage of relative humidity $(\%)$, rainfall $(\mathrm{mm})$, solar radiation (w/m2), and wind speed (m.s-1). The mini station was located near the bays. Due to the different average maximum levels of ambient temperature, rain, and humidity, this study, according to the literature, divided the year into two seasons, according to the harvests carried out: rainy season (RS), from March to June; and non-rainy season (nRS), from August to November.

Meteorological data were evaluated using the general linear model (GLM). In contrast, semen data was examined using the repeated measurement instruction of the MIXED procedure (Proc MIXED) from the Statistical Analysis Systems software (SAS Institute Inc., Cary/NC, USA). The model included the fixed effects of the bull's age, ejaculate (harvest week), season, average maximum temperature, humidity, and the interaction between them. The sperm morphology and plasma membrane integrity data of the ejaculates were transformed into a square root before analysis. Pearson's correlation coefficients were used to analyze the association between semen parameters and age, season, and meteorological data. The generalized estimation equation (GEE) test was used to determine the differences between the individual semen quality variables (categorical). The differences were considered statistically significant at $P<0.05$. The Shapiro-Wilk normality test was applied to test whether the variables under study assumed normal distribution or not, and the data not being standard, the Kruskal-Wallis.

\section{RESULTS}

Meteorological data obtained on environmental conditions in different seasons such as temperature, relative humidity, precipitation, and solar radiation $(P<0.05)$ were different when comparing the rainy season (RS) and non-rainy season (nRS), while wind speed did not show a significant difference $(P>0.05)$ between periods (Table 1$)$. The average physical and morphological characteristics of all buffalo ejaculates described by rainy and non-rainy periods are contained in Table 2.

The immediate analyzes pertinent to the physical and morphological characteristics of the ejaculates were carried out and the volume of $3.4 \pm 2.0 \mathrm{~mL}$ corresponded to the RS, swirling (mass movement) of $4.4 \pm 0.5$; motility of $80.4 \pm 5.6 \%$; a vigor of $4.4 \pm 0.4$; concentration of $657,300 \pm 237,865.1 \times 106 \mathrm{sptz} / \mathrm{mL}$; major defects $9.0 \pm 2.6 \%$; defects smaller than $11.2 \pm 3.9 \%$; total defects of $20.2 \pm 5.3 \%$ and plasma membrane integrity (PMI) of $84.8 \pm 5.6 \%$, whereas in $n R S$, the results were $4.0 \pm 2.1 \mathrm{~mL}$; a mass movement of $3.0 \pm 1.0$; motility of $56.2 \pm 13.4 \%$; a vigor

Table 1. Variables found in the different seasons based on data obtained by the Meteorological Station WS-GP1 (AT DeltaDevicesLtda, Cambridge, UK) in Santarém, Pará, from March to November 2016 (mean \pm SD)

\begin{tabular}{|c|c|c|c|c|c|}
\hline Season & $\begin{array}{c}\text { Temperature } \\
\left({ }^{\circ} \mathrm{C}\right)\end{array}$ & $\begin{array}{l}\text { Relative humidity } \\
\qquad(\%)\end{array}$ & Rainfall (mm) & $\begin{array}{l}\text { Solar radiation } \\
\left(\mathrm{W} / \mathrm{m}^{2}\right)\end{array}$ & $\begin{array}{l}\text { Wind speed } \\
(\mathrm{m} . \mathrm{s}-1)\end{array}$ \\
\hline Rainy season* & $28.1 \pm 1.8^{\mathrm{a}}$ & $89.4 \pm 10.2^{\mathrm{a}}$ & $2,418 \pm 309^{a}$ & $232.7 \pm 301.3^{\mathrm{a}}$ & $1.6 \pm 0.7^{\mathrm{a}}$ \\
\hline Non-rainy season** & $29.4 \pm 1.9^{b}$ & $79.0 \pm 10.6^{\mathrm{b}}$ & $381 \pm 95^{b}$ & $260.6 \pm 314.0^{\mathrm{b}}$ & $2.0 \pm 1.0^{\mathrm{a}}$ \\
\hline
\end{tabular}

${ }^{*}$ Rainy season $=$ March to June, ${ }^{* *}$ non-rainy season = August to November 2016; a,b Means with different superscript letters within a column were significantly different between seasons $(P<0.05)$.

Table 2. Average physical and morphological characteristics of buffalo ejaculates, in the rainy and non-rainy seasons (n=100), Santarém, Pará, 2016

\begin{tabular}{|c|c|c|}
\hline Seminal parameters & Rainy season* & Non-rainy season** \\
\hline Volume (ml) & $3.4 \pm 2.0^{\mathrm{a}}$ & $4.0 \pm 2.1^{\mathrm{a}}$ \\
\hline Whirlwind (0-5) & $4.4 \pm 0.5^{\mathrm{a}}$ & $3.0 \pm 1.0^{\mathrm{b}}$ \\
\hline Motility (\%) & $80.4 \pm 5.6^{\mathrm{a}}$ & $56.2 \pm 13.4^{\mathrm{b}}$ \\
\hline Vigor(0-5) & $4.4 \pm 0.4^{\mathrm{a}}$ & $3.0 \pm 1.0^{\mathrm{b}}$ \\
\hline Concentration $\left(\mathrm{x} 10^{6} \mathrm{sptz} / \mathrm{mL}\right)$ & $657,300 \pm 237,865.1^{\mathrm{a}}$ & $586,000 \pm 291,925.9^{\mathrm{a}}$ \\
\hline Major defects (\%) & $9.0 \pm 2.6^{a}$ & $20.8 \pm 9.9^{b}$ \\
\hline Minor defects (\%) & $11.2 \pm 3.9^{a}$ & $27.5 \pm 6.3^{\mathrm{b}}$ \\
\hline Total defects (\%) & $20.2 \pm 5.3^{\mathrm{a}}$ & $48.3 \pm 9.3^{b}$ \\
\hline Plasma membrane integrity (\%) & $84.8 \pm 5.6^{\mathrm{a}}$ & $57.9 \pm 12.4^{\mathrm{b}}$ \\
\hline
\end{tabular}

* Rainy season $=$ March-June, ${ }^{* *}$ non-rainy season $=$ August to November; ${ }^{\text {a,b }}$ Different lowercase letters on the same line indicate a significant difference between periods $(P<0.05)$. 
of 3.0 \pm 1.0 ; concentration of $586,000 \pm 291,925.9 \times 106 \mathrm{sptz} /$ $\mathrm{mL}$; defects greater than $20.8 \pm 9.9 \%$; defects smaller than $27.5 \pm 6.3 \%$; total defects of $48.3 \pm 9.3 \%$ and PMI of $57.9 \pm 12.4 \%$. There was a statistical difference $(P<0.05)$ for the parameters mass movement, motility, vigor, major defects, minor defects, total defects, and integrity of the plasma membrane between the two periods.

Data on heart rate, surface temperature (head, back, groin, and scrotum) differed statistically between periods $(P<0.05)$. However, the RR and RT referring data did not differ between periods $(P>0.05)$. The HR data showed a statistical difference when comparing the periods, with the highest values observed in the rainy season $(54 \pm 10.9 \mathrm{bpm})$. While the head region (STH) $(36.2 \pm 2.4)$, groin (GST) $(34.6 \pm 2.2)$, scrotum (STS) (32.3 \pm 2.0$)$, and back region (STB) $(35.1 \pm 2.1)$ also showed significant differences $(P<0.05)$, however, the highest values were found in the non-rainy season (Table 3).

\section{DISCUSSION}

According to Köppen (Afi) classification, the best air conditions in the region with the hot and humid climate surpass the recommended for creating buffaloes throughout the year, demonstrating that buffaloes can experience thermal discomfort.

In the present study, we can corroborate this research because the animals presented thermal discomfort in the described region, represented by the buffalo's physiological and reproductive changes. We are still considering that the ideal climatic conditions for the growth and reproduction of buffalo are air temperature between 13 and $18^{\circ} \mathrm{C}$, associated with average relative humidity between 55 and $65 \%$, medium heat stroke, and wind speed between 5 and $8 \mathrm{~km} / \mathrm{h}$ (Marai \& Haeeb 2010, Garcia 2013). These ideal climatic conditions described were not observed and recorded in the region.

Buffaloes were kept in the same management conditions during the two study periods (rainy and non-rainy), offering the same amount of food (concentrated and voluminous), mineral salt, bathing twice a day, constant shading water supply ad libitum. Even maintaining the routine, there were changes in these animals' physiological parameters; the surface temperatures (head, back, groin, and scrotum) were increased during the non-rainy period. The rise in surface temperature may have been an attempt to thermoregulation through cutaneous evaporation of heat conducted from the central core of the body to peripheral vascularization (Almeida et al. 2015). According to Garcia (2013), in bioclimatological terms, an animal can have an elevated body temperature when it absorbs an excessive amount of heat from the medium when its capacity to dissipate body heat is reduced, the association of both factors is established. Regardless of the cause, this temperature rise's consequences are manifested in a cascade of events to try to adjust the animal organism to the imposed challenge.

The increase in the ambient temperature and other physiological variables can alter the vagal tone, intensifying the cardio accelerator and vasoconstrictor centers' activity, thus increasing the HR (Souza et al. 2007). According to Guyton \& Hall (2002), this effect presumably results because the excessive heat increases the cell membrane's ionic permeability, resulting in accelerating the self-excitation process, unlike what happened in the experiment, in which the heart rate decreased during the non-rainy period. The increase in heart rate was not associated with an increase in the ambient temperature, which occurred in the non-rainy period; this can be explained by the animals'-controlled thermoregulation mechanism and the handling used, which did not cause thermal discomfort.

The increase in rectal temperature indicates that heat release mechanisms have become insufficient to maintain homeothermy (Matos 2008). In the experiment's case, there were no changes in the rectal temperature or the respiratory rate, which, according to Silva et al. (2011), is the first thermal discomfort indicator. It was deduced that it was due to the handling of the animals subjected to shading installs. They managed to control their thermoregulation only with skin evaporation maintaining thermal balance.

In males, thermal stress translates into reduced seminal quality and lower viability of sperm (Sansone et al. 2000, Vale et al. 2007, Bhakat et al. 2015). Thermal stress can lead to interruptions in reproductive processes through two general mechanisms (Castro et al. 2017); the first is the failure of the homeokinetic mechanisms present in the animal organism, capable of regulating body temperature that can compromise reproductive function. This can cause loss of libido and spermatogenesis disturbances in males (Jöchle \& Lamond 1980, Henry et al. 2017, Vale 2007). Because the animal starts to spend its energy maintaining its thermoregulation point due to thermal discomfort, it ends up eating little, impairing the absorption of necessary nutrients essential for the functioning of reproductive hormones. Per second, we have the failure of homeokinetic systems to regulate reproduction, increasing body temperature around its regulated set point, which can compromise cells' function and the consequent reproduction processes. In the present study, we can observe the negative influence of thermal stress on reproductive parameters, as there was a significant difference between rainy and nonrainy periods.

In Brazil, buffaloes reared in the south-central regions tend to show reproductive seasonality (Jacomini 1989). Those reared in the north of the country show continuous polystyrene activity, reproducing throughout the year if they are well-nourished and well managed (Vale 1988). In the hot

Table 3. Average physiological parameters, before the buffalo semen collections, in the rainy and non-rainy seasons (n=100) in Santarém, Pará, 2016

\begin{tabular}{|c|c|c|c|c|c|c|c|}
\hline Season & $\begin{array}{c}\text { HR } \\
(\mathrm{bpm})\end{array}$ & $\begin{array}{c}\mathrm{RR} \\
(\mathrm{mpm})\end{array}$ & $\begin{array}{l}\text { RT } \\
\left({ }^{\circ} \mathrm{C}\right)\end{array}$ & $\begin{array}{l}\text { STH } \\
\left({ }^{\circ} \mathrm{C}\right)\end{array}$ & $\begin{array}{l}\text { STB } \\
\left({ }^{\circ} \mathrm{C}\right)\end{array}$ & $\begin{array}{l}\text { GST } \\
\left({ }^{\circ} \mathrm{C}\right)\end{array}$ & $\begin{array}{l}\text { STS } \\
\left({ }^{\circ} \mathrm{C}\right)\end{array}$ \\
\hline Rainy season & $54 \pm 10.9^{a}$ & $22 \pm 6.8^{\mathrm{a}}$ & $38.3 \pm 0.8^{a}$ & $33.3 \pm 2.5^{\mathrm{a}}$ & $33.6 \pm 2.1^{\mathrm{a}}$ & $32.3 \pm 2.2^{\mathrm{a}}$ & $30.3 \pm 2.0^{\mathrm{a}}$ \\
\hline Non-rainy season & $48 \pm 11.8^{\mathrm{b}}$ & $23 \pm 6.7^{\mathrm{a}}$ & $38.2 \pm 0.8^{\mathrm{a}}$ & $36.2 \pm 2.4^{b}$ & $35.1 \pm 2.1^{b}$ & $34.6 \pm 2.2^{\mathrm{b}}$ & $32.3 \pm 2.0^{\mathrm{b}}$ \\
\hline
\end{tabular}

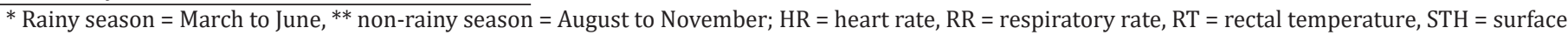

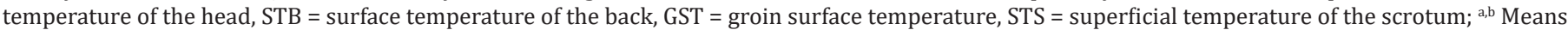
with different superscript letters within a column were significantly different between seasons $(P<0.005)$. 
and humid tropical region of the Amazon, the best time to obtain semen would be between January and June, as reported by Vale (1994). Therefore, this study aimed to identify the effects of the humid tropical climate on physiological and reproductive aspects of buffalo ejaculates that could alter these aspects between the two climatic periods existing in the Lower Amazon mesoregion (rainy and non-rainy). Relevance studies have demonstrated a significant difference in other regions, as described by Mohan \& Sahni (1990), Galli et al. (1993), Sansone et al. (2000).

They claim that in temperate regions of the world, it appears that the semen is of better-quality during winter and spring than in summer and autumn, that is, in milder temperatures, giving more thermal comfort to the animal.

Thus, as reported by Di Francesco (2010), who found a significant number of normal sperm in the spring $(69.6 \%)$ and also findings by Ferrer et al. (2010), who reported a lower number of normal sperm in summer (66.2\%), the experiment had a significant difference between rainy and non-rainy periods.

Sperm volume data did not show significant differences, agreeing with the studies of some authors in swamp buffalo (Koonjaenak et al. 2007) and river buffalo (Heuer et al. 1987, Bahga \& Khokar 1991, Khan et al. 1997, Tiwari et al. 2011, Bhakat et al. 2015).

The study carried out by Andrade (2016) showed a significant difference during the year since the data diverge with results obtained by him, which concluded he did not hear significant changes throughout the year, and this may be due to work was carried out in a humid subtropical climate. Like Mayahi et al. (2014), Bhakat et al. (2015) found differences in motility between the winter and summer periods. The present study found differences between the rainy period $80.4 \pm 5.6 \%$ and the non-rainy period $56.2 \pm 13.4 \%$.

Thus, the studies carried out in different regions, the effect of periods considered unfavorable, and the non-rainy period negatively influence the sperm quality of the animals, which makes us think about the importance of including special handling so that buffalo can be appropriately used throughout the year.

\section{CONCLUSIONS}

The buffalo reproductive parameters, such as whirling, motility, vigor, significant defects, minor defects, total defects, and plasma membrane integrity, proved to be better in the rainy than non-rainy, overcoming delays between periods.

The physiological parameters that were influenced by the non-rainy period, in comparison to the rainy season, were heart rate and surface temperature, head, back, groin, and scrotum $(P<0.05)$.

Specific management in the non-rainy period is necessary so that the thermal stress is not a determining factor in reducing the reproductive quality of the buffaloes.

Necessary means to improve the animal welfare are important such as regular baths, or provide access to areas of rivers or lakes and shading, preventing buffaloes exposure to the unfavorable thermal environment.

Conflict of interest statement.- The authors declare that there are no conflicts of interest.

\section{REFERENCES}

Ablas D.S., Titto E.A.L., Pereira A.M.F., Titto C.G. \& Leme T.M.C. 2007. Comportamento de bubalinos a pasto frente a disponibilidade de sombra e água para imersão. Ciênc. Anim. Bras. 8(2):167-175. <https://dx.doi. org/10.5216/cab.v8i2.1339>

Almeida J.C.F., Silva G.P. \& Silva J.A.R. 2015. Influência climática nos mecanismos fisiológicos e comportamentais de bubalinos na região amazônica. $42^{\circ}$ Congresso Brasileiro de Medicina Veterinária, 1ํㅡㄹ Congresso Sul-Brasileiro da Anclivepa, Curitiba, PR, p.726-730.

Andrade G.0. 2016. Avaliação da sazonalidade nas características sexuais de touros bubalinos (Bubalus bubalis) criados em clima subtropical úmido (19o latitude sul). Master's Thesis, Universidade Federal de Minas Gerais, Escola de Veterinária, Belo Horizonte. 68p.

Bahga C.S. \& khokar B.S. 1991. Effect of different seasons on concentration of plasma luteinizing hormone and seminal quality vis-à-vis freezability of buffalo bulls (Bubalus bubalis). Int. J. Biometeorol.35(4):222-224. <https:// dx.doi.org/10.1007/bf01047289><PMid:1778653>

Barbosa O.R., Zeoula L.M., Sirena R.M., Oliveira R.A., Berticelli T. \& Ornellas S.A. 2007. Comparação nas respostas termoregulatórias de búfalos e bovinos em confinamento. 1. Temperatura da superfície do corpo e taxa de sudação. Anais 44응 Sociedade Brasileira de Zootecnia/Pastagens, Unesp, Jaboticabal, SP. (CD-ROM)

Barros P.M.H., Nichi M., Cortada C.N.M., Carvalho N.A.T., Baruselli P.S., Barnabe R.C. \& Barnabe V.H. 2007. Semen evaluation of Murrah buffalo bulls using sperm functional tests. Ital. J. Anim. Sci. 6(Supl.2):772-774. <https://dx.doi. org/10.4081/ijas.2007.s2.772>

Bhakat M., Mohanty T.K., Gupta A.K., Prasad S., Chakravarty A.K. \& Khan H.M. 2015. Effect of season on semen quality parameters in Murrah buffalo bulls. Buffalo Bull. 34(1):100-112.

Castro S.R.S., Morini A.C., Silva A.S.L., Neves K.A.L., Minervino A.H.H., Meneses A.A.M. \& Vale W.G. 2017. Influence of seasonality on buffalo semen. Anim. Vet. Sci. 5(3):45-51. <https://dx.doi.org/10.11648/j.avs.20170503.12>

CBRA 2013. Manual para Exame Andrológico e Avaliação de Sêmen Animal. 3 a ed. Colégio Brasileiro Reprodução Animal, Belo Horizonte. 104p.

Di Francesco S. 2010. Effect of season on reproductive performances in buffalo species (Bubalus bubalis). Doctoral Dissertation in Production and Health of Food of Animal Origin, Universita' Degli Studi di Napoli Federico II, Napoli. 165p.

Ferrer A., Montes I. \& Alcalá Y. 2010. Influencia de la época del año en las características del semen fresco del búfalo de agua. Cien. Tecnol. Ganadera $4(1): 53-58$.

Galli A., Bornaghi V., Balduzzi D., Buttazzoni L. \& Aleandri R. 1993. Sexual behaviour and semen quality relating to italian buffalo. Anais Proceedings 3rd World Buffalo Congress, Varna, Bulgaria, p.562-570.

Garcia A.R. 2006. Influência de fatores ambientais sobre as características reprodutivas de búfalos do rio (Bubalus bubalis). Revta Ciênc. Agrárias 45(supl.):1-13.

Garcia. A.R. 2013. Conforto térmico na reprodução de bubalinos criados em condições tropicais. Revta Bras. Reprod. Anim. 37(2):121-130.

Guyton A. \& Hall J.E. 2002. Tratado de Fisiologia Médica. Guanabara Koogan, Rio de Janeiro. $1014 \mathrm{p}$.

Henry M., Brito M.F., Neves B.P., Auler P.A., Almeida J., Andrade G.O., Becerra V.B. \& Bergmann L. 2017. Peculiarities of the buffalo species for andrological evaluation - results of four years of study and weekly semen collection schedule. Anim. Reprod. 14(supl.1):1225-1223. <https://dx.doi. org/10.21451/1984-3143-AR0005>

Heuer C., Tahir M.N. \& Amjad H. 1987. Effect of season on fertility of frozen buffalo semen. Anim. Reprod. Sci. 13(1):15-21. <https://dx.doi. org/10.1016/0378-4320(87)90115-1> 
Jacomini J.O. 1989. Aspectos do ciclo estral e do comportamento sexual de búfalos (Bubalus bubalis, var. bubalis). Master's Thesis in Veterinary Medicine, Escola de Veterinária, Universidade Federal de Minas Gerais, Belo Horizonte. 80p.

Jöchle W. \& Lamond D.R. 1980. Control of Reproductive Functions in Domestic Animals. Martinus Nijhoff. 248p.

Joshi B.C., McDowell R.E. \& Sadhu D.P. 1968. Body surface evaporation rates at low and high temperatures in Murrah buffalo. J. Dairy. Sci. 51(10):16891692. <https://dx.doi.org/10.3168/jds.S0022-0302(68)87253-4> $<$ PMid:5693163>

Khan M.S., Bajwa M.A. \& Tahir M. 1997. Effect of diet and season on semen characteristics in Nili-Ravi buffalo bulls. Buffalo Bull. 16(3):60-63.

Koonjaenak S., Chanatinart V., Aiumlamai S., Pinyopumimintr T. \& RodriguezMartinez H. 2007. Seasonal variation in semen quality of swamp buffalo bulls (Bubalus bubalis) in Thailand. Asian. J. Androl. 9(1):92-101.<https:// dx.doi.org/10.1111/j.1745-7262.2007.00230.x> <PMid:17187160>

Köppen W. \& Geiger R. 1928. Klimate der Erde. Verlag Justus Perthes, Gotha. (Wall-Map $150 \mathrm{~cm} \times 200 \mathrm{~cm}$ )

Marai I.F.M. \& Haeeb A.A.M. 2010. Buffalo's biological functions as affected by heat stress. Rev. Livest. Sci. 127(2/3):89-109. <https://dx.doi.org/10.1016/j. livsci.2009.08.001>

Matos L.B. 2008. Conforto térmico e eficiência da inseminação artificial em tempo fixo em búfalas leiteiras mantidas em sistemas silvipastoris na Amazônia Oriental. Master's Thesis in Animal Science, Universidade Federal do Pará. Belém. 81p.

Mayahi S., Mamouei M., Tabatabaei S. \& Mirzadeh K. 2014. Reproductive characteristics and thyroidal function in relation with season in Khuzestan buffalo (Bubalus bubalis) bulls. Vet. Res. Forum 5(3):201-205.

Ministério da Agricultura 2011. Dados de rebanho bovinos e bubalinos do Brasil. Avaiable at <http://www.agricultura.gov.br/arq_editor/file/ Dados\%20de\%20rebanho\%20bovino\%20e\%20bubalino\%20do\%20 Brasil_2011.pdf> Accessed on Feb. 3, 2017.

Mohan G. \& Sahni K.L. 1990. Efficiency of semen production in buffalo bulls, p.14-16. In: Acharya R.M., Lokeshwar R.R. \& Kumar S. (Eds), Recent Advances in Buffalo Research. Vol.3.
Rasul Z., Anzar M., Jalali S. \& Ahmad N. 2000. Effect of buffering systems on post-thaw motion characteristics, plasma membrane integrity, and acrosome morphology of buffalo spermatozoa. Anim. Reprod. Sci. 59(1/2):31-41. <https://dx.doi.org/10.1016/s0378-4320(00)00070-1><PMid:10804274>

Sally S.A., Aida I.M., Amany A.T. \& Mohamed M.AB.D.E. 2015. Effect of seasonal variations on semen quality and fertility of Egyptian water buffalo (Bubalus Bubalis) Bulls. Res. J. Pharm. Biol. Chem. Sci. 6(6):1059-1069.

Sansone G., Nastri M.J.F. \& Fabbrocini A. 2000. Storage of buffalo (Bubalus bubalis) semen. Anim. Reprod. Sci. 62(1/3):55-76. <https://dx.doi. org/10.1016/s0378-4320(00)00154-8><PMid:10924820>

Silva J.A.R., Araújo A.A., Lourenço Junior J.B., Santos N.F.A., Garcia A.R. \& Nahúm B.S. 2011. Conforto térmico de búfalas em sistema silvipastoril na Amazônia Oriental. Pesq. Agropec. Bras. 46(10):1364-1371. <https:// dx.doi.org/10.1590/S0100-204X2011001000033>

Souza B.B., Silva R.M.N., Marinho M.L., Silva G.A., Silva E.M.N. \& Souza A.P. 2007. Physiological parameters and heat tolerance index of sindi breed bovine in the semi-arid of Paraiba. Ciênc. Agrotec. 31(3):883-888. <https:// dx.doi.org/10.1590/S1413-70542007000300040>

Tiwari R., Mishra G.K., Shukla M.K., Singh R.B., Saxena S.K. \& Siddiqui M.U. 2011. Seasonal variations in semen production of Murrah buffalo bulls. Indian J. Anim. Reprod. 32(2):5-7.

Vale W.G. 1988. Fisiologia da reprodução na búfala, p.1-28. In: Vale W.G. (Ed.), Bubalinos: fisiologia e patologia da reprodução. Fundação Cargill, Campinas.

Vale W.G. 1994. Collection, processing and deep freezing of buffalo semen. Buffalo J. (supl.2):65-81.

Vale W.G. 2002. Reproductive management of buffalo male aimming semen production for artificial insemination. Proceedings 1st Buffalo Symposium of Americas, Belém, PA, p156-171.

Vale W.G. 2007. Effects of environment on buffalo reproduction. Ital. J. Anim. Sci. 6(2):130-142. <https://dx.doi.org/10.4081/ijas.2007.s2.130>

Vale W.G. 2011. Avances biotecnológicos em reproducción de búfalos. Revta Tecnología em Marcha 24(5):89-90.

Vilela R.A. 2013. Efeito do ambiente térmico na fisiologia adaptativa de bubalinos. Tese de Doutorado, Faculdade de Zootecnia e Engenharia de Alimentos, Universidade de São Paulo, São Paulo, SP. 110p. 